Jambura Fish Processig Journal Vol.1 No.1 Tahun 2019

\title{
KARAKTERISTIK HIDROGEL DARI IOTA KARAGINAN DAN PVA (POLY-VINYL ALCOHOL) DENGAN METODE FREEZING-THAWING CYCLE
}

\author{
Dina Fransiska*1; Ahmad Reynaldi2 \\ 1 Balai Besar Riset Pengolahan Produk dan Bioteknologi Kelautan dan Perikanan, \\ J. Ks.Tubun, Petamburan 6, Slipi, Jakarta Pusat 10260, Jakarta, Indonesia \\ 2 Program Studi Perikanan, Fakultas Perikanan dan Ilmu Kelautan, Universitas Padjadjaran \\ Jl. Raya Bandung - Sumedang Km 2, Jatinangor 45363, Jawa Barat, Indonesia \\ *Korespondensi: frans_dina@yahoo.com \\ (Diterima 13-02-2020 / Dipublikasi 13-02-2020)
}

\begin{abstract}
ABSTRAK
Hidrogel dengan polimer PVA sudah banyak digunakan saat ini. Hidrogel berbasis Poly Vinyl Alcohol (PVA) dibentuk dengan siklus pembekuan mempunyai beberapa kegunaan seperti kandungan air yang banyak serta tidak beracun. Bahan yang digunakan yaitu lota karaginan yang diekstrak dari rumput laut Eucheuma spinosum., Poly Vinyl Alcohol (PVA), aquadest. Pembuatan hidrogel diawali dengan formulasi karagenan dengan PVA pada beberapa variasi konsentrasi yaitu $0 \%$ (kontrol); $0,5 \% ; 1 \%$; $1,5 \% ; 2 \%$ dan $2,5 \%$, serta PVA yang ditambahkan sama yaitu $10 \%$ dan $200 \mathrm{ml}$ akuades. Karakteristik fisik dari hidrogel yang dihasilkan yaitu uji daya serap air, uji fraksi gel dan uji tensile strength. lota karaginan yang diuji memiliki karakteristik kadar abu 27,51\%, kadar abu tak larut asam 0,9\%, kadar sulfat 29,53 \%, viskositas $43 \mathrm{cP}$, kekuatan gel 44,2 $\mathrm{g} / \mathrm{cm}^{2}$, ALT sebesar 2,5 × $10^{4}$ dan negatif $E$. Coli namun kadar air masih tinggi yaitu $27,07 \%$. Pembentukan hidrogel dengan freezing-thawing dan iradiasi sinar gamma terjadi ketika polimer PVA dan iota karaginan berikatan silang serta membentuk kristal yang dapat menyerap air/hidrofilik. Konsentrasi iota karaginan 2,5\% merupakan konsentrasi terbaik untuk pembuatan hydrogel PVA-iota dengan nilai daya serap air 947,19\%, fraksi gel 74,66 \% dan kuat tarik sebesar 2,69 kg/cm².
\end{abstract}

Kata kunci: Daya serap air; Eucheuma spinosum; raksi gel; Hidrogel PVA-iota; Kuat tarik.

\begin{abstract}
Hydrogels with PVA polymers are widely used today. Hidrogel berbasis Poly Vinyl Alcohol (PVA) dibentuk dengan siklus pembekuan mempunyai beberapa kegunaan seperti kandungan air yang banyak serta tidak beracun. Bahan yang digunakan yaitu lota karaginan yang diekstrak dari rumput laut Eucheuma spinosum., Poly Vinyl Alcohol (PVA), aquadest. Hydrogel production begins with carrageenan formulation with PVA at several concentrations, namely $0 \%$ (control); $0.5 \% ; 1 \% ; 1.5 \% ; 2 \%$ and $2.5 \%$, and the same PVA added are $10 \%$ and $200 \mathrm{ml}$ of distilled water. The physical characteristics of the hydrogel produced are water absorption, gel fraction test and tensile strength test. The carrageenan iota tested has the characteristic ash content of $27.51 \%$, acid insoluble ash content of $0.9 \%$, sulfate content of $29.53 \%$, viscosity of $43 \mathrm{cP}$, gel strength of $44.2 \mathrm{~g} / \mathrm{cm} 2$, ALT of $2.5 \times 104$ and negative $E$. Coli but the water content is still high at $27.07 \%$. Hydrogel formation by freezing-thawing and gamma ray irradiation occurs when the PVA polymer and carrageenan iota are cross-linked and form crystals that can absorb water/hydrophilic. Carrageenan $2.5 \%$ iota concentration is the best concentration for making PVA-iota hydrogel with a water absorption value of $947.19 \%$, gel fraction $74.66 \%$ and tensile strength of $2.69 \mathrm{~kg} / \mathrm{cm}^{2}$.
\end{abstract}

Keywords: Water absorption; Eucheuma spinosum; Gel fraction; PVA-iota hydrogel; Tensile strength. 


\section{PENDAHULUAN}

Karaginan merupakan polimer hidrofilik yang struktur utamanya berupa polisakarida, berasal dari berbagai macam rumput laut seperti Eucheuma, Chondrus, Gigartina dan Fucellaria. Menurut Craigie (1978) dalam Peranginangin (2013), karaginan terdapat dalam dinding sel rumput laut atau matriks intraselulernya dan karaginan merupakan bagian penyusun yang besar dari berat kering rumput laut dibandingkan dengan komposisi yang lain. Sementara menurut Winarno (1996), karaginan merupakan getah rumput laut yang diekstrak dengan air atau larutan alkali dari spesies tertentu dari kelas Rhodophyceae (alga merah). Karaginan disusun dari unit D-galaktosa yang berikatan dengan $\beta$ (1,3)-D- galactose-4-sulfat dan a (14)-3,6-anhidro-D-galaktosa.

Ada beberapa jenis karaginan yang umum digunakan, tiga jenis utama karaginan digolongkan dari jumlah dan posisi dari gugus sulfat pada pengulangan unit disakarida : kappa karaginan (satu gugus sulfat pada posisi 4 dari $\beta$-D-galaktosa, I-karaginan (satu gugus sulfat pada posisi 4 dari $\beta$-D-galaktosa dan satu gugus sulfat pada posisi 2 dari a-3,6 anhidro-D-galaktosa) dan $\lambda$-karaginan (satu gugus sulfat pada posisi 2 dari $\beta$-D-galaktosa dan dua gugus sulfat pada posisi 2 dan 6 dari a-3,6 anhidro-D-galaktosa (Lendlein \& Sisson, 2011). Rumput laut yang berbeda menghasilkan karaginan yang berbeda pula. Euchema denticulatum adalah sumber penting dari iota karaginan, serta Gigartina pistillata dan Chondrus crispus memproduksi lamda karaginan (Lendlein \& Sisson, 2011).

lota karaginan dihasilkan dari rumput laut Euchema spinosum. lota karaginan merupakan jenis karaginan dengan kandungan sulfat berada di antara lamda dan kappa karaginan. lota karaginan dapat membentuk gel yang elastis. Menurut Bubnis (2000) iota karaginan memiliki gel berwarna bening dengan tidak mengeluarkan cairan (sineresis), gel stabil dalam keadaan beku atau dilelehkan. Salah satu yang membedakan jenis dari karaginan adalah kadar sulfatnya. Kadar sulfat iota karaginan berada pada $28-35 \%$ serta gel yang lebih kuat dengan adanya ion $\mathrm{Ca}^{2+}$. lota karaginan ditandai dengan adanya ikatan 1,3-Dgalaktosa-4-sulfat dan ikatan 1,4 dari unit 3,6anhidro-D-galaktosa-2-sulfat. lota karaginan terbentuk karena hilangnya sulfat pada atom C6 dari _(nu)-karaginan sehingga terbentuk 3,6-anhidro-D-galaktosa yang selanjutnya menjadi iota karaginan (Glicksman 1983).

Polyvinyl alkohol (PVA) dengan rumus molekul $\left[\mathrm{CH}_{2} \mathrm{CH}(\mathrm{OH})-\right]_{n}$ - merupakan salah satu jenis polimer hidrofilik yang tidak toksis, tidak larut dalam air dan larut dalam air panas $>80^{\circ} \mathrm{C}$ pada batas konsentrasi < $20 \%(\mathrm{~b} / \mathrm{v})$. PVA yang dipolimerisasi cara pemanasan, menghasilkan gel yang jika dikeringkan pada suhu kamar menghasilkan film transparan. Namun demikian, film ini dapat 
menggembung kembali dalam air berupa gel yang rapuh (Erizal dan Rahayu 1998).

lota karagenan berfungsi sebagai basis gel, bahan penstabil dan bahan peningkat viskositas. Kombinasi antara PVA dan karaginan dapat membentuk polimer hydrogel yang sangat membantu dalam berbagai bidang, seperti bidang kesehatan.

Hidrogel adalah salah satu jenis makromolekul polimer hidrofilik yang berbentuk jaringan berikatan silang, mempunyai kemampuan mengembang dalam air (swelling), serta memiliki daya diffusi air yang tinggi. Oleh karena sifat fisik yang khas tersebut, pada awalnya hidrogel disintesis untuk digunakan sebagai matriks pengekang/ pelepasan obat, kontak lensa, immobilisasi enzim dan sel (Erizal 2006). Hidrogel digunakan dalam berbagai bidang seperti pertanian, kesehatan dan kebutuhan seharihari. Contoh hidrogel dalam bidang biomedis yaitu sebagai pembalut luka bakar. Hal ini disebabkan karena sifat hidrogel yang mampu mengekang kelembaban air dan mendinginkan luka bakar, serta aman terhadap tubuh.

Hidrogel dengan polimer PVA sudah banyak digunakan saat ini. Hidrogel berbasis poly(vinyl alcohol)(PVA) dibentuk dengan siklus pembekuan mempunyai beberapa kegunaan seperti kandungan air yang banyak serta tidak beracun. Sebelumnya telah banyak dilakukan penelitian mengenai hidrogel berbasis karaginan, seperti penelitian
Erizal (2008) yang mensintesis hidrogel dari PVP $15 \%$ dan kappa-karaginan 2\% menggunakan sinar gamma $25 \mathrm{kGy}$ untuk pembalut luka pada tikus wistar, adapun penelitian Gadri et al. (2014) yang mensintesis hidrogel berbasis iota-karaginan dengan metode freezing and thawing cycle. Penelitian ini bertujuan untuk mengetahui konsentrasi terbaik karaginan dan poly-vinyl alcohol dalam pembuatan hydrogel.

\section{METODE PENELITIAN}

\section{Bahan}

Bahan yang digunakan yaitu lota karaginan yang diekstrak dari rumput laut Eucheuma spinosum., Polyvinyl Alcohol (PVA), aquadest.

\section{Alat}

Alat yang digunakan adalah autoclave, Inkubator $35 \pm 1 \circ \mathrm{C}$, viscometer Brookfield model LVF dan LVT, gelas beker $250 \mathrm{ml}$, wadah sampel bahan kaca (diameter $7 \mathrm{~cm}$, tinggi $4 \mathrm{~cm}$ ), tutup wadah kotak persegi bahan kaca (ukuran 8x8 cm), alat TAXT Plus/10396, plunger/probe (diameter 12,5 mm), Instronn Tester Model buatan Toyoseiki, Jepang, cetakan dumbbeil.

\section{Karakterisasi Bahan Baku lota Karaginan}

Mutu rumput laut yaitu uji kadar air (BSN 2006), Uji Kadar Abu (BSN 2006), Uji Kadar Abu Tak Larut Asam (BSN 2006), uji sulfat metode gravimetric, ALT (Angka Lempeng Total) (BSN, 2006), E. Coli (BSN, 2006), Uji Viskositas (JECFA, 2007), Kekuatan Gel (McHugh, 2003). 
Pembuatan Hidrogel lota Karaginan

Pembuatan hidrogel diawali dengan formulasi karagenan dengan PVA pada beberapa variasi konsentrasi dapat dilihat pada tabel. PVA ditimbang sebanyak $10 \mathrm{~g}$ Kemudian dicampurkan dalam $100 \mathrm{ml}$ akuades dan di panaskan dalam autoklaf. Karaginan ditimbang sesuai variasi, lalu dilarutkan dalam $100 \mathrm{ml}$ akuades, dipanaskan dan diaduk dalam hotplate sampai suhu $80^{\circ}$ C. Larutan PVA dicampurkan kedalam larutan karaginan kemudian dipanaskan hingga suhu 800 C selama 10-15 menit. Setelah formula selesai, dimasukkan dalam cetakan plastik berukuran $30 \times 16 \mathrm{~cm}$. Plastik kemudian diseal dengan alat sealer lalu didiamkan sebentar. Cetakan plastik yang telah berisi formula hidrogel diletakkan di freezer refrigerator pada suhu -200 C selama 18 jam. Setelah proses freezing, dilakukan thawing larutan yang beku pada suhu ruang selama 6 jam. Perlakuan ini disebut satu siklus. Siklus yang digunakan pada penelitian ini yaitu 3 siklus. Hidrogel lalu diiradiasi dengan sinar-y dosis $25 \mathrm{kGy}$ (laju dosis 2,5 kGy/jam) dalam iradiator IRKA PATIR-BATAN. Tujuan iradiasi pada dosis $25 \mathrm{kGy}$ adalah untuk sintesis dan sterilisasi hidrogel secara simultan (Erizal, 2008).

Rancangan percobaan dilakukan dengan penambahan iota karaginan yang berbeda yaitu $0 \%$ (kontrol); 0,5\%; $1 \%$; $1,5 \% ; 2 \%$ dan $2,5 \%$, serta PVA yang ditambahkan sama yaitu $10 \%$ dan $200 \mathrm{ml}$ akuades.

Tabel 1. Formula hydrogel

\begin{tabular}{ccccccc} 
Jenis Bahan & \multicolumn{7}{c}{ Formula (\%) } \\
\cline { 2 - 7 } PVA & $\mathbf{1}$ & $\mathbf{2}$ & $\mathbf{3}$ & $\mathbf{4}$ & $\mathbf{5}$ & $\mathbf{6}$ \\
I-Karagenan & 10 & 10 & 10 & 10 & 10 & 10 \\
Aquadest & 0 & 0,5 & 1 & 1,5 & 2 & 2,5 \\
& 100 & 100 & 100 & 100 & 100 & 100 \\
\hline
\end{tabular}

Untuk mengetahui karakteristik fisik dari hidrogel yang dihasilkan, maka perlu diuji Daya serap air (Daya Serap Air), Uji Fraksi Gel dan Uji Tensile Strength (tegangan tarik), sehingga dapat diketahui hidrogel dengan karakteristik terbaik.

\section{Uji Daya serap air}

Hidrogel dipotong atas 3 bagian bentuk kubus ukuran $2 \times 2 \times 0,5 \mathrm{~cm}^{2}$, lalu dikeringkan dalam oven pada suhu $60^{\circ} \mathrm{C}$ selama 24 jam. Kemudian hydrogel direndam dalam air suling selama 24 jam. Selanjutnya hidrogel dikeluarkan dari bejana perendaman, air di permukaan hidrogel bawah dikeringkan dengan kertas tissue dan hidrogel ditimbang (Wd). Kemudian hidrogel dikeringkan dalam oven pada suhu $60^{\circ} \mathrm{C}$ selama 24 jam dan hidrogel kering dtimbang kembali (Ws). Daya serap air dihitung dengan persamaan berikut:

$$
\text { Daya serap air }=\frac{W s-W d}{W d}
$$

\section{Uji Fraksi Gel}

Hidrogel dipotong atas 3 bagian bentuk kubus ukuran $2 \times 2 \times 0,5 \mathrm{~cm}^{2}$, lalu dikeringkan dalam oven pada suhu $60^{\circ} \mathrm{C}$ selama 24 jam. Selanjutnya, ditimbang $\left(\mathrm{W}_{0}\right)$. Kemudian hydrogel kering dikemas dalam 
kawat kasa stainless steel ukuran 300 mesh. Selanjutnya, kawat kasa yang mengandung hydrogel direndam dalam air suling pada suhu $70^{\circ} \mathrm{C}$ dalam shaker dan digoyang dengan kecepatan $100 \mathrm{rpm}$ selama 24 jam untuk menghilangkan zat-zat yang tidak bereaksi. Akhirnya, hydrogel dikeluarkan dari shaker dan dikeringkan kembali dalam oven pada suhu $60^{\circ} \mathrm{C}$ hingga berat konstan. Hidrogel ditimbang kembali (W1), dan fraksi gel dihitung dengan persamaan berikut.

$$
\% \text { Fraksi Gel }=\frac{W 1}{W 0} \times 100 \%
$$

\section{Uji Tegangan Tarik (Tensil Strength)} Tegangan tarik adalah salah satu parameter yang penting dari hidrogel yang mewakili sifat kelenturannya. Pengujiannya dilakukan dengan menggunakan alat Instronn Tester Model buatan Toyoseki, Jepang dengan kecepatan $30 \mathrm{~mm} /$ menit pada suhu $30^{\circ} \mathrm{C}$ berdasarkan metode yang tertera dalam ASTM. Hidrogel dengan ketebalan berkisar $0,2 \mathrm{~cm}$ lebar $3 \mathrm{~cm}$ panjang $5 \mathrm{~cm}$ dicetak dengan alat dumbbeil untuk mendapatkan bentuk standar pengukuran. Selanjutnya hidrogel dengan bentuk dumbbeil tersebut pada kedua ujungnya dijepit dengan alat penjepit khusus, dan mesin dinyalakan pada posisi on, maka akan terjadi proses penarikan pada salah satu posisi penjepit. Ukuran tegangan putus pada hidrogel dari mesin diklukur pada saat hidrogel putus di posisi tengahnya. Tegangan tarik hidrogel dihitung berdasarkan persamaan berikut:

Tegangan Tarik $=$ F $/ \mathrm{A}$

$\mathrm{F}=$ Beban dari alat hingga bahan putus $(\mathrm{Kg})$

$A=$ Luas penampang bahan $\left(\mathrm{cm}^{2}\right)$

\section{HASIL DAN PEMBAHASAN \\ Karakteristik Fisika dan Kimia iota karaginan}

Pengujian karakteristik fisika pada karaginan penting agar dapat mengetahui standar bahan baku yang digunakan sesuai kebutuhan produksi. Pengujian fisik karaginan meliputi viskositas dan kekuatan gel. lota karaginan didapatkan dari ekstraksi rumput laut Eucheuma spinosum. Hasil analisis dibandingkan dengan data dari FAO (Food Agriculture Organization) dan FCC (Food Chemical Codex). Hasil analisis fisik iota karaginan disajikan dalam tabel berikut.

Tabel 2. Hasil uji fisika dan kimia

\begin{tabular}{lccc}
\hline \multirow{2}{*}{ Parameter } & \multicolumn{1}{c}{ lota } & \multicolumn{2}{c}{ Standar } \\
\cline { 3 - 4 } & Karaginan & FAO & FCC \\
\hline $\begin{array}{l}\text { Viskositas } \\
\text { (cP) }\end{array}$ & $43 \pm 2,65$ & Min. 5 & - \\
$\begin{array}{l}\text { Kekuatan } \\
\left.\text { gel (g/cm }{ }^{2}\right)\end{array}$ & $44,2 \pm 0,83$ & - & - \\
$\begin{array}{l}\text { Kadar air } \\
(\%)\end{array}$ & $27,07 \pm 0,11$ & Maks.12 & Maks.12 \\
$\begin{array}{l}\text { Kadar abu } \\
(\%)\end{array}$ & $27,51 \pm 0,36$ & $15-40$ & Maks.35 \\
$\begin{array}{l}\text { Kadar abu } \\
\text { tak larut } \\
\text { asam (\%) }\end{array}$ & $0,69 \pm 0,07$ & Maks.2 & Maks. 1 \\
\hline Kadar Sulfat & $29,53 \pm 0,23$ & $15-40$ & - \\
\hline
\end{tabular}

Tabel 2. tersebut menunjukkan bahwa parameter iota karaginan sebagai bahan baku pembuatan hidrogel telah memenuhi standar FAO dan FCC, hanya 
kadar air saja yang belum memenuhi standar. Pembahasan karakteristik fisika dan kimia iota karaginan dijelaskan sebagai berikut.

Viskositas merupakan daya aliran molekul yang terdapat dalam suatu larutan. Pengujian viskositas dilakukan untuk mengetahui tingkat kekentalan suatu larutan. Kekentalan tersebut dinyatakan dalam satuan centipoises (cPs) (Darmawan et al. 2014). Nilai rata-rata viskositas iota karaginan yaitu 43 $\pm 2,65$ dan sudah memenuhi standar yang ditetapkan FAO dan FCC yaitu minimal $5 \mathrm{cP}$. Pengukuran viskositas dilakukan pada suhu $75^{\circ} \mathrm{C}$ karena pada suhu tersebut larutan masih stabil dan belum membentuk gel.

Viskositas dipengaruhi oleh adanya kandungan sulfat dalam karaginan. Kandungan sulfat menyebabkan larutan tersebut menjadi kental. Menurut Basmal et al. (2005), semakin tinggi kandungan sulfat maka kekuatan gel akan semakin rendah tetapi nilai kekentalan menjadi tinggi. Hal ini dikarenakan fraksi sulfat yang tinggi menyebabkan viskositasnya menjadi tinggi. Moirano (1977) menambahkan bahwa viskositas pada karaginan disebabkan oleh adanya daya tolak menolak antara grup sulfat yang bermuatan negative disepanjang rantai polimernya, sehingga menyebabkan rantai polimer kaku dan tertarik kencang, sehingga molekul air terikat pada molekul karaginan yang mengakibatkan meningkatnya viskositas.

http://ejurnal.ung.ac.id/index.php/ffpj/issue/arch
Kekuatan gel adalah gaya yang dibutuhkan untuk memecah permukaan gel dalam waktu tertentu dibagi jarak yang ditempuh. Prinsipnya adalah besar dari gaya yang dibutuhkan sampai permukaan gel pecah (McHugh 2003). Pemanasan hingga $80^{\circ} \mathrm{C}$ bertujuan untuk melarutkan seluruh karaginan, bila belum mencapai suhu tersebut karaginan susah larut dan membentuk gumpalan. Hasil uji didapatkan nilai sebesar $44,2 \pm 0,83 \mathrm{~g} / \mathrm{cm}^{2}$ dimana nilai tersebut sedikit berbeda dengan penelitian Gadri et al. (2014) dimana kekuatan gel iota karaginan sekitar $96 \pm 5.51$. Nilai tersebut bila semakin kecil maka kandungan sulfatnya semakin tinggi. Seperti yang diketahui, bahwa kandungan sulfat yang tinggi pada iota karaginan menyebabkan kekuatan gelnya menjadi rendah. Tingginya kadar sulfat dapat menyebabkan terputusnya ikatan 3,6-anhidroD-galaktosa sehingga kekuatan gelnya menurun (Ulfah, 2009).

Nilai kadar sulfat diperoleh rata-rata $29,53 \pm 0,23 \%$ dimana nilai tersebut sudah memenuhi standar FAO yaitu sekitar 15-40 $\%$. Sementara menurut Doty (1985) kandungan sulfat pada iota karaginan lebih dari $30 \%$. Kadar sulfat berkaitan erat dengan gugus sulfat yang ada pada struktur kimia iota karaginan. lota karaginan terdiri atas unit-unit ulangan antara ikatan 1,3 dari unit $D$ galaktosa-4-sulfat dan ikatan 1,4 dari unit 3,6 anhidro-D-galaktosa-2-sulfat (Campo et al., 2009). Gugus tersebut menyebabkan kadar 
sulfat yang tinggi yang secara langsung berpengaruh terhadap viskositas dan kekuatan gel iota karaginan. Kadar sulfat dapat dipengaruhi oleh kadar air dan tipe karaginan. Pertambahan umur panen cenderung menyebabkan kadar sulfat tepung karaginan mengalami penurunan.

Nilai rata-rata kadar air iota karaginan yaitu $27,07 \pm 0,11 \%$ dimana nilai tersebut masih melebihi standar yang ditetapkan FAO dan FCC yaitu maks. $12 \%$. Kadar air yang tinggi bisa disebabkan oleh beberapa faktor, diantaranya proses penjemuran yang belum sepenuhnya kering karena intensitas panas matahari yang rendah. Penjemuran karaginan dilakukan 2-3 hari tergantung dari intensitas panas matahari (Peranginangin 2013). Kadar air karaginan yang dihasilkan dapat dipengaruhi oleh beberapa faktor, diantaranya adalah jenis dan umur rumput laut yang digunakan serta teknik ekstraksi yang dipakai dalam pembuatan karaginan (Darmawan et al., 2014). Dengan hasil tersebut, perlu adanya pengeringan kembali agar dihasilkan karaginan dengan kadar air maksimal $12 \%$.

Kadar abu dalam bahan pangan menunjukkan seberapa besar mineral yang terkandung di dalamnya (Apriyantono et al., 1989). Kadar abu didapatkan nilai rata-rata sebesar $27,51 \pm 0,36 \%$ dimana nilai tersebut masih memenuhi standar FAO sebesar 15-40 $\%$ dan standar FCC sebesar $35 \%$. Karaginan mengandung berbagai macam ion, seperti ion natrium, kalium, kalsium dan magnesium.
Adanya ion Kalium dalam $\mathrm{KCl}$ pada proses presipitasi karaginan akan meningkatkan kadar abu karaginan yang dihasilkan (Darmawan et al. 2014). Keseimbangan kation dalam larutan karaginan dapat menentukan viskositas serta kekuatan gel dari karaginan tersebut, yang nantinya menentukan kegunaan dari karaginan sebagai pengemulsi, penstabil dan pembuat gel (Campo et al. 2009).

Abu tidak larut asam merupakan garamgaram klorida yang tidak larut asam yang sebagian adalah garam-garam logam berat dan silika. Kadar abu tidak larut asam merupakan salah satu kriteria dalam menentukan tingkat kebersihan dalam proses pengolahan (Basmal et al. 2003). Kadar abu tak larut asam iota karaginan didapatkan sebesar 0,69 $\pm 0,07 \%$ dan nilai tersebut masih dibawah standar yang ditetapkan FAO yaitu maksimal $2 \%$ dan standar FCC yaitu maksimal $1 \%$. Dengan demikian, proses pengolahan iota karaginan tersebut tidak banyak terkontaminasi oleh logam berat serta silika, baik itu dalam proses penanganan maupun saat ekstraksi karaginan.

\section{Uji Mikrobiologi}

Uji angka lempeng total (ALT) digunakan untuk menghitung jumlah mikroba aerob atau anaerob dalam produk perikanan. Pertumbuhan mikroorganisme aerob dan anaerob setelah contoh diinkubasikan dalam media agar pada suhu $35 \pm 1^{\circ} \mathrm{C}$ selama $24-$ 
$48 \pm 1$ jam mikroorganisme ditumbuhkan pada suatu media agar, maka mikroorganisme tersebut akan tumbuh dan berkembang biak dengan membentuk koloni yang dapat langsung dihitung. Hasil uji ALT iota karaginan menunjukkan nilai $2,5 \times 10^{4}$ koloni/g. Hal ini menunjukkan kandungan mikroorganisme yang cukup tinggi pada karaginan tersebut, koloni tersebut melebihi batas maksimum yang ditetapkan BSN (2009) untuk kategori jeli agar sebesar $1 \times 10^{4}$ koloni/g. Kandungan mikroorganisme yang tinggi diduga karena proses ekstraksi, presipitasi ataupun penepungan yang kurang steril dan kandungan air yang banyak menyebabkan mikroba dapat tumbuh pada karaginan tersebut.

Uji penentuan coliform dan E. coli dilakukan dengan uji pendugaan coliform, setelah diinkubasi selama 48 jam, tabung tabung berisi sampel dan LTB dilihat apakah timbul gas atau tidak. Hasil pengamatan menunjukkan bahwa seluruh tabung dengan pengenceran $10^{-1}, \quad 10^{-2}, \quad 10^{-3}$ tidak menghasilkan gelembung dan gas, hanya terlihat warna larutan menjadi keruh. Sehingga dapat disimpulkan bahwa tabungtabung tersebut negatif dari coliform dan $E$. coli.

\section{Karakteristik Hidrogel}

Mengacu pada penelitian Erizal (2008) kemungkinan reaksi yang terjadi adalah adanya radikal atom yang muncul dari

http://ejurnal.ung.ac.id/index.php/jfpj/issue/arch masing-masing polimer dan berikatan silang membentuk reaksi kopolimerisasi. Hidrogel kemudian diuji karakteristiknya.

Uji rasio daya serap air merupakan persen antara berat dari gel yang mengembang dikurangi berat gel yang kering dibagi gel kering. Berat gel kering yang dihitung adalah saat hidrogel dikeringkan kembali 24 jam setelah mengembang. Dari grafik bisa dijelaskan bahwa penambahan konsentrasi iota karaginan dapat meningkatkan daya serap air, konsentrasi 2,5 $\%$ iota menyerap air hingga 947,19\% sementara nilai terendah berada pada konsentrasi iota $0 \%$ sebesar $372,6 \%$. Nilai konsentrasi $2 \%$ yang turun bisa disebabkan oleh adanya degradasi dan kekuatan fisiknya turun serta pembentukan gel yang tidak sempurna.

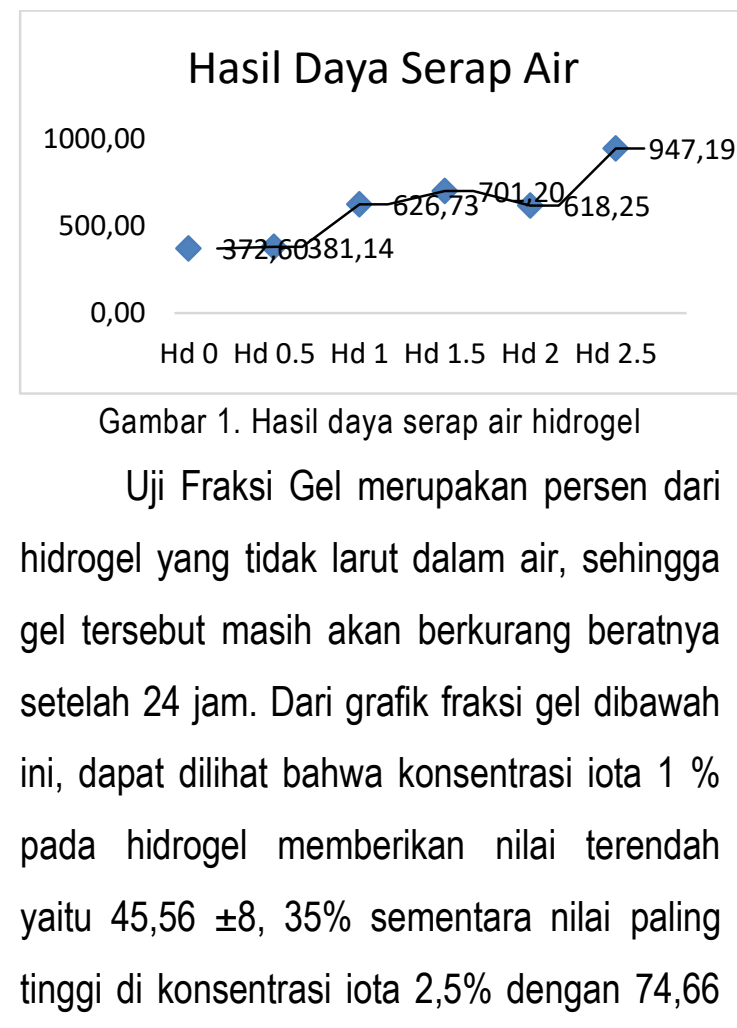


$\pm 5,53 \%$. Konsentrasi disini tidak selalu berbanding lurus dengan naiknya fraksi gel. Menurut Rosiak et al (2009) fraksi gel meningkat dengan naiknya dosis, namun dalam beberapa kasus fraksi gel menurun setelah mencapai maksimal. Fraksi gel optimum dipengaruhi oleh berat molekul, konsentrasi gel dan dosis radiasi. Kemungkinan adanya pembentukan gel yang tidak sempurna sehingga hidrogel konsentrasi $1 \%$ nilainya paling rendah, gel yang tidak terbentuk kemudian larut dalam air.

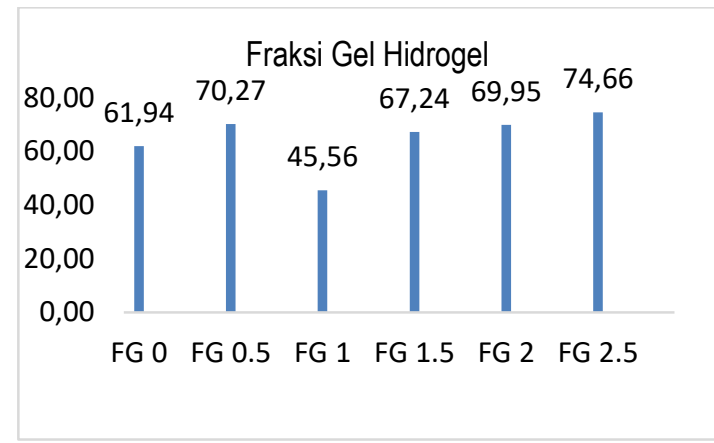

Gambar 2. Grafik fraksi gel hidrogel

Uji kuat tarik merupakan nilai maksimum gaya yang diproduksi jika dilakukan uji tarik. Semakin tinggi gaya yang diproduksi maka kekuatan tariknya akan semakin besar (Herliany 2013). Hasil tertinggi uji tegangan tarik pada pengujian pertama berada di konsentrasi 2,5\% sebesar 2,6880 $\mathrm{kg} / \mathrm{cm}^{2}$ dan paling rendah pada konsentrasi $1 \%$ sebesar $0,3551 \mathrm{~kg} / \mathrm{cm}^{2}$. Dari hasil tersebut dapat dikatakan bahwa konsentrasi berpengaruh terhadap kekuatan tarik dari hidrogel, semakin tinggi konsentrasi hidrogel maka kekuatan tarik pun semakin tinggi. Hal ini diduga semakin banyak ikatan silang yang terjadi di antara rantai yang memberi efek pada kekuatan tarik dari gel tersebut (Wach 2005).

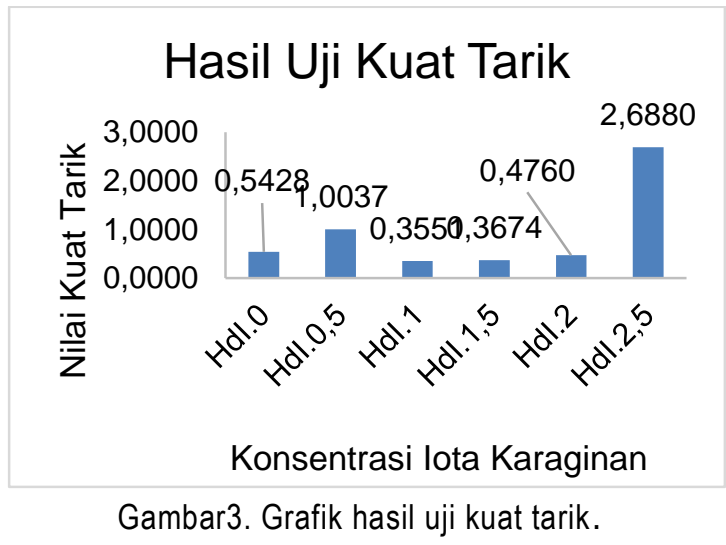

\section{SIMPULAN}

1. lota karaginan yang diuji memiliki karakteristik kadar abu 27,51\%, kadar abu tak larut asam 0,9\%, kadar sulfat $29,53 \%$, viskositas $43 \mathrm{cP}$, kekuatan gel $44,2 \mathrm{~g} / \mathrm{cm}^{2}$, ALT sebesar $2,5 \times 10^{4}$ dan negatif $E$. Coli namun kadar air masih tinggi yaitu $27,07 \%$,

2. Pembentukan hidrogel dengan freezingthawing dan iradiasi sinar gamma terjadi ketika polimer PVA dan iota karaginan berikatan silang serta membentuk kristal yang dapat menyerap air/hidrofilik.

3. Konsentrasi iota karaginan 2,5\% merupakan konsentrasi terbaik untuk pembuatan hidrogel PVA-iota dengan nilai daya serap air $947,19 \%$, fraksi gel $74,66 \%$ dan kuat tarik sebesar 2,69 $\mathrm{kg} / \mathrm{cm}^{2}$. 


\section{DAFTAR PUSTAKA}

Apriyantono, A., Fardiaz, D., Puspitasari, N., Sodarnawati, Budiyanto. 1989 Analisis Pangan. Bogor: Pusat Antar Universitas Pangan dan Gizi IPB .

Basmal, J., Syarifuddin, Ma'ruf, W. 2003. Pengaruh Konsentrasi Larutan Potassium Hidroksida terhadap Mutu Kappa-Karaginan yang Diekstraksi dari Euchema cotonni. Jurnal Penelitian Perikanan Indonesia. 11(8); 95-103.

Basmal, J., Suryaningrum, T., Yennie, Y. 2005. Pengaruh Kosentrasi dan Rasio Larutan Potassium Hidroksida dan Rumput Laut terhadap Mutu Karaginan Kertas. Jurnal Penelitian Perikanan Indonesia. (11); 29-38.

BSN. 2006. Cara uji kimia-bagian 1: Penentuan kadar abu pada produk perikanan. Jakarta: Badan Standardisasi Nasional.

BSN. 2006. Cara uji kimia-Bagian 2: Penentuan kadar air pada produk perikanan. Jakarta: Badan Standardisasi Nasional.

BSN. 2006. Cara uji mikrobiologi-Bagian 1: Penentuan coliform dan Escherichia coli pada produk perikanan. Jakarta: Badan Standardisasi Nasional.

BSN. 2006. Cara uji mikrobiologi-Bagian 3: Penentuan angka lempeng total (ALT) pada produk perikanan. Jakarta: Badan Standardisasi Nasional.

Bubnis, W. 2000. Carrageenan. Retrieved from http://www.fmcbiopolymer.com/

Campo, V., Kawano, D., Silva Junior, D. I. 2009. Carrageenans: Biological Properties, Chemical Modifications and Structural Analysis. Carbohydrate Polymers. 77:167-180.

Darmawan, M., Peranginangin, R., Syarief, R., Kusumaningrum, I., Fransiska, D. 2014. Pengaruh Penambahan Karaginan Untuk Formulasi Tepung
Puding Instan. JPB Perikanan. 9(1): 83-95.

Doty, M. 1985. Farming The Red Seaweed, Euchema for Carrageenans. Micronesica IX. (1):59-73.

Erizal. 2006. Prosiding Simposium Nasional Polimer VI.111-115.

Erizal. 2008. The Effect Of Hydrogel Dressing Copolyme Poli (vinylpirrolidone) (PVP) -k-Carrageneenan Prepared by Radiation and Healing Times on The Radius Reductions Burn Injuried Of Wistar White Rat. . Indo J Chem. 8(2):272.

Erizal, Rahayu, C. 1998. Karakterisasi Hidrogel Poli(Vynil Alkohol) (PVA) Hasil Polimerisasi Radiasi. Penelitian dan Pengembangan Aplikasi Isotop dan Radiasi, 137-144.

Gadri, A., Mulyanti, D., Aprilianti, S. 2014. Formulasi Pembalut Luka Hidrogel Berbasis I-Karaginan dengan Metode Freezing and Thawing Cycle. Prosiding SNaPP2014 Sains, Teknologi, dan KesehataN. 4(1): 163170.

Glicksman. 1983. Food Hydrocolloids. Florida: CRC Press Inc Boca Raton.

Herliany, E., Santoso, J., Salamah, E. 2013. Karakteristik Biofilm Berbahan Dasar Karaginan. Jurnal Akuatika. 4(1): 1020.

Holloway, J. L., Palmese, A. M. 2013. Acta Biomater. 9:5013-5021.

JECFA. 2007. Compedium of Food Additive Specifications. Roma, Italia.

Lendlein, A., Sisson, A. (2011). Handbook of Biodegradable Polymers. Weinheim: Willey-VCH.

McHugh, D. 2003. A Guide to The Seaweed Industry. Canberra: FAO FISHERIES TECHNICAL PAPER 441 School of Chemistry.

Moirano, A. 1977. Sulfated polysaccharides. In H. Graham, Food Colloids (pp. 
347-381). Westport, Connecticut: The AVI Publishing Company Inc.

Pektifabrik, A. K. 1978. Carrageenan. Denmark: Lillekensved.

Peranginangin, R., Sinurat, E., Darmawan, M. (2013). Memproduksi Karaginan dari Rumput Laut. Jakarta: Penebar Swadaya.

Rosiak, J. E. 2002. Radiation Formatin of Hydrogels for Biomedical Applications. Poland: Institute of Applied Radiation Chemistry, Technical University of Lodz Wroblewskiego 15.

Sankalia, M. G., Mashru, R. C., Sankalia, J. A., Sutariya, V. B. 2006. Stability improvement of alpha-amylase entrapped in kappa-carrageenan beads:Physicochemical characterization and optimization using composite index. International Journal of Pharmaceutics. 321: 1-14.

Ulfah, M. 2009. Pemanfaatan iota karaginan (Eucheuma spinosum) dan kappa karaginan (Kappaphycus alvarezii) sebagai sumber serat untuk meningkatkan kekenyalan mie kering. Bogor: Program Teknologi Hasil Perikanan Fakultas Perikanan dan IImu Kelautan Institut Pertanian Bogor.

Wach, R., Al., e. 2005. Polysaccharide derivatives crosslinked by ionizing radiation. Proceeding of the 8th Polymers for Advanced Technologies International Symposium, Budapest, Hungary. 13-16.

Winarno, F. 1996. Teknologi Pengolahan Rumput Laut. . Jakarta : Pustaka Sinar Harapan. 